UDK 378.14: 004.738.5

Oleg Spirin 1 , Volodymyr Eremeev ${ }^{2}$

${ }^{1}$ Institute of Information Technologies and Learning Tools of NAES of Ukraine, Kiev, Ukraine

${ }^{2}$ Melitopol Bohdan Khmelnytsky State Pedagogical University, Melitopol, Ukraine

\title{
THE USAGE OF CLOUD SERVICES IN THE PROCESS OF PROFESSIONAL TRAINING OF PROGRAMMERS AT HIGHER EDUCATIONAL INSTITUTIONS
}

\author{
DOI: $10.14308 /$ ite 000639
}

In the article the state of the art and the main tendencies of cloud computing development are analyzed. The importance of cloud technologies application in education is grounded. The directions of their appliance are examined in higher education, in particular as for the creation of the cloud-oriented learning scientific environment at educational institutions. The advantages of transfer of IT-infrastructure of higher educational institutions into the cloud form are shown (the economy of funds for purchase of software and renovation of computer database; the reduction of the need for specially equipped premises; the creation of an open educational environment). The main directions of the research study of cloud technologies application in the process of professional training of programmers are characterized, among them there are: 1) formation of skills of the cloud services use for the professional tasks solving; 2) formation of skills of the development of cloud applications, deployment of cloud infrastructure, cloud applications and data bases security support. The description of cloud services that can be used in the process of programming learning and usage of training projects (Ideone, Codenvy, DbDesigner) are provided. The brief description of the possibilities of the Amazon platform usage for formation of cloud software development skills is provided.

Keywords: cloud computing, cloud services, cloud-oriented learning and scientific environment, professional training of programmers, programming in "cloud".

\section{Introduction}

\section{The problem statement in general aspect and its connection with important practical tasks.}

One of the main trends of the development of the global IT industry nowadays is the improvement and expansion of the cloud technologies that influence the global development of business, finance, state administration, medicine, education and other spheres of life and activity of a human [15]. Leading analytical companies have notified the rapid development of the cloud solutions and services market over the last few years, as well as the market related services, the increase of expenses for cloud services. In particular, the demand is increasing for services of the IT infrastructure transfer and high-performance loads into cloud (artificial intelligence, Internet of stuff, analytics, etc.), for the rent of software, etc. [5]. The Ukrainian cloud technology market is also developing. The cloud segment is growing, unlike the overall recession in the internal IT market. In particular, according to data of the analysts of the company "Networks and Business" in 2016, its scope has increased by $35 \%$ in comparison to 2015. Among the reasons of this, experts 
identify the increase of business owners' awareness about the advantages of cloud services; the opportunity for enterprises to obtain modern computer infrastructure without updating their own IT equipment; to create a flexible IT environment with minimal funding; the reduction of informational risks and the increase of safety level, etc. [9].

The above tendencies of the cloud computing development and services influence the field of education significantly, as they create new opportunities of improving the IT infrastructure for educational institutions, the means of access to educational information and the organization of the process of study. On the other hand, it is a growing demand for skilled professionals for this sphere, trained at higher educational institutions.

The importance of cloud technologies application in education is underlined in the "National Report about the State and Prospects of the Development of Education in Ukraine" (2016) [14]. In particular, to the tendencies of the formation of informational educational space its authors include the development of technology of cloud computing and virtualization of corporate, public and hybrid ICT infrastructures, as well as the formation and development of networks of ICT services providers, in particular ICT-outsourcers of cloud services and network of Centers for data processing (Data Center) [14, p. 162].

So, the development of the educational and research environment (ERE) of higher educational institutions on the basis of cloud computing technology is an actual trend of modernization of contemporary higher education. It is related to the distribution of convenient, flexible and scalable systems of organizing access to electronic resources and services, allowing collective work with software applications, overcoming of geographical and time restraints, increasing of mobility of all subjects of learning and research and other factors. The wide implementation of cloud computing facilities and services, in particular, with the aim of maintenance of access to the world and national informational systems of research and educational activity support, assists to solve many of the urgent tasks in the education sphere, namely: increasing the level of accessibility and quality of education; strengthening of the links of education, science and industry; the improvement of the open educational and scientific environment of higher educational institutions; expanding the cooperation of educational and scientific institutions; the creation of corporate structures aimed at interaction with the university sector, the participation in solving of social and economic problems of society, as well as improvement of the intensity of scientific search and the process of professional training of highly qualified personnel, etc. So, these technologies and services become an instrument of implementation of the principles of human-centeredness, equal access to education, strengthening of postulates of open education in the pedagogical systems $[2$, p. 57; 4, p. 94].

It is worth to emphasize the significant importance of the above mentioned factors for organization of professional training in higher educational institutions of specialists for the field of computer science, in particular programmers. The training of the programmers and the formation of their professional competencies requires the creation and continuous improvement of the ERE of universities, an important component of which are modern information and communication technologies. The substantial obstacle to this is the lack of funding for public higher educational institutions, which makes timely update of the hardware and software impossible, which is necessary for training of specialists. The means of overcoming this problem are cloud technologies, since, as Vakalyuk T. A. states, "the usage of cloud technologies in the field of education can serve as a replacement of the usual expensive software tools and their service" [26, p. 18].

\section{The analysis of research and publications in which the solution to this problem was initiated.}


The professional training of programmers in higher educational institutions is the subject of numerous studies, in particular: theoretical and methodological principles of professional training of IT specialists (Grishko L. V., Kolyada M. G., Osadchyj V. V., Padalko N. Y., Seidametova Z. S., Tischenko S. I.) and engineers (Gorbatyuk R. M, Dzhezhyla O. M., Ignatyuk O. A., Lazarev M. I., Oleksenko V. M., Romanovskyj O. G., Khomenko V.G.); methodical approaches to training of programming to programmers (Ilyasova F. S., Mintij I. S., Semerikov S. O.); introduction of a competent approach to the professional training of programmers (Vinnuk M. O., Sedov V. Ye.); the usage of information and communication tools in the professional training of IT professionals (Kogut U. P., Matvijchuk L. A., Stryuk A. N.).

The theoretical and methodological principles of the introduction of cloud technologies in higher educational institutions and the creation on their basis of modern student scientific-oriented and educational environment are highlighted in the works of Bykov V. Yu. [2; 4], Vakalyuk T. A. [24], Vojtovich I. S. [18], Gorbatyuk R. M. [8], Litvinova S. G. [13], Markova O. M., Oleksyuk V. P., Potapchuk O.I. [8], Rybakova L. V. [16], Seidametova Z. S. [6; 17; 19], Semerikov S. O., Sergienko V. P. [18], Stryuk A. M., Shishkina M. P. [4; 13; 20; 21] and others.

Different aspects of educational using of cloud technologies and services are examined in the studies of foreign researchers $[1 ; 11 ; 22]$. In particular, the features of using the cloud computing infrastructure provided by Microsoft, Google and Amazon Web Service in the educational organizations and its benefits for students and teachers are examined in the paper of Lakshminarayanan R., Kumar B., and Raju M. [11]. For example, Alkhansa A., Shakeabubakor A., Sundararajan E., and Hamdan A. [1] explore advantages of using cloud technologies in research, such as availability of various tools and applications for analyses and collecting data, for managing and organizing references, for communication with peers and experts, the absence of constraints, the access to cloud resources from anywhere any time that has an active Internet connection, etc. [1, p. 155]. They offer the approach to applying of cloud services for enhancing the productivity of university research activities, increasing competitiveness and flexibility of educational institutions.

Particular attention is given now to the study of the methodological foundations of the creation of cloud-oriented learning environments (COLE), as well as their widespread implementation in higher educational institutions. Similar environments can fully cover the activities of universities or can be intended for providence of specific directions of training of specialists with the possibility of further integration into the general network. In particular, to the problems of creation of a cloud-oriented learning environment of higher educational institutions are dedicated the works of Bykov V. Yu. and Shishkina M. P. [2], Vakalyuk T. A. [26], Khmil N. A. [10] and other scholars, peculiarities of the COLE for the training of bachelors of informatics are studied in works of Vakalyuk T. A. [25; 27; 28].

In particular, in her work [28] Vakalyuk T. A. provides the complex description of the cloudoriented support system of training (COSST) of bachelor of informatics, which includes the forms, methods and tools of students' teaching. She points out that the main forms of educational activity of students in the COLE are training sessions, practical training, independent work, control activities and research work. These forms can be effectively implemented by means of COSST by bachelors of informatics, namely: training classes can be conducted in the form of lectureconversation, lecture-discussion, video lecture, lecture-consultation, lecture-presentation [28, p. 66]; practical training can be accomplished in the form of online laboratory and practical works, seminar lessons and webinars; for independent work accomplishment can be used individual lessons, consultations, group online projects; for knowledge control online testing is assigned [28, p. 68]; research work can be conducted with usage of online consultations and discussions in specially created problem groups [28, p. 70]. COSST provides the means for the effective usage in the online environment of various teaching methods: verbal, visual, practical, problematic training, explanatory-illustrative, researching, heuristic, method of projects, etc. [28, p. 71]. In COSST such cloud-oriented means of educational activity of students are implemented: the means of training management (electronic journal and calendar located in the cloud); the means of the presentation of educational materials (electronic library, presentations, video files, electronic textbooks, located in 
the cloud, cloud data base); the means of common activity (software located in the cloud); the means of knowledge control (tests, group on-line projects); the means of communication (discussion, chat, online consultations, webinar) [28, p. 72].

In the work [27], the researcher presents the description of the cloud-oriented learning environment designed for bachelors' of informatics training. Investigated by her, COLE contains such components: targeting (the aims of training, the field standards of higher education); functions (managerial, organizational, educational, consulting, communicative); managerial (the cloudoriented means of training management and assessment of learning activity); organizational (the distribution of users' access rights, the organization of subjects' communities); content-methodical (the traditional and cloud-oriented forms, methods and means of training); communicational (the cloud-oriented means of communication of subjects of interaction that determine the styles of communication); effective [27, p. 55]. The researcher defines two important components of the professional training of bachelors of informatics: training of programming and implementation of collective program projects. The methodical system of COLE contains the traditional and cloudoriented components, aimed at carrying out of the corresponding educational tasks. In particular, the author suggests using of the cloud-oriented compilers with support for various programming languages in the learning process (ideone.com), as well as the web-oriented means for automatic check of the programming tasks solving, which help the teacher in preparation for tests, examinations, module works, and students to check independently the received results (Internet portal e-olymp.com) [27, p. 57].

In the work [25] Vakalyuk T. A. gives the advantages of usage of the cloud service of NEO LMS to creation of COLE for the training of bachelors of informatics, defined on the base of the analysis of several systems of education management (Learning Management Systems (LMS): Geenio, Moodle, Oracle, Learner Nation, iSpring, Canvas, Schoology, NEO LMS.

\section{The formulation of the goals of the article (settlement of the task).}

The aim of the study is to analyze the present state of implementation of the cloud technologies in education and to determine the directions of their usage in the process of professional training of programmers in higher educational institutions.

\section{The results of the study}

\subsection{The cloud information and communication technologies in education}

The definition of the cloud technologies will be provided as "Cloud computing is a model for enabling ubiquitous, convenient, on-demand network access to a shared pool of configurable computing resources (e.g., networks, servers, storage, applications, and services) that can be rapidly provisioned and released with minimal management effort or service provider interaction. This cloud model is composed of five essential characteristics, three service models, and four deployment models." [12, p. 2].

The architecture of cloud computing contains three types of the services: the base of the cloud is Infrastructure as a Service, IaaS, the platform is imposed on it as a service (Platform as a Service, $\mathrm{PaaS}$ ) and then the software as a service (Software as a Service, SaaS). The deployment of clouds is carried out according to one of the models: the private clouds (private or rented clouds of enterprises), the public (public) clouds, the hybrid clouds (contain several clouds of different types) [17, p. 106-107].

The IaaS type architecture allows the user to design his own infrastructure in the cloud independently and manage it (to create virtual networks, to add virtual equipment, to install the necessary software, etc.). The usage of the PaaS architecture implies that the information infrastructure is managed by a cloud service provider, which gives the access to the operating systems, the database management systems, development tools, and others to the user. The usage of a SaaS-like architecture implies that the provider manages the information infrastructure and computing platform, he provides the user with only available software, access to which is realized with the help of a web browser [16, p. 111]. The advantages and disadvantages of defined cloud 
services architectures are given in the work of Shyshkina M. P. [20, p. 115], presented in the table 1 .

Table №1.

The advantages and disadvantages of cloud services architectures

\begin{tabular}{|c|c|c|}
\hline Model & Advantages & Disadvantages \\
\hline SaaS & 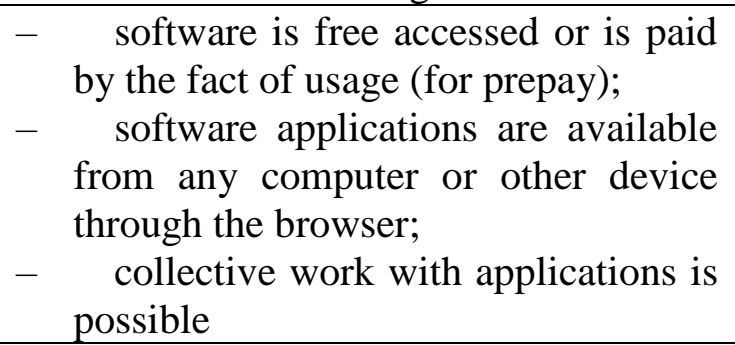 & $\begin{array}{l}\text { applications of general purpose that } \\
\text { exist as a service are not always } \\
\text { suitable for specific professional } \\
\text { tasks. }\end{array}$ \\
\hline $\mathrm{PaaS}$ & $\begin{array}{l}\text { - the possibility to create software } \\
\text { applications quickly and at low price; } \\
\text { - } \text { the facilities to develop applications } \\
\text { for their own needs or make them } \\
\text { publicly available }\end{array}$ & $\begin{array}{l}\text { - limits the developer by languages } \\
\text { and tools, offered by the provider; } \\
\text { if the provider ceases to supply the } \\
\text { services, it may be not possible to } \\
\text { transfer software applications to } \\
\text { another platform }\end{array}$ \\
\hline IaaS & $\begin{array}{l}\text { - elimination of the need of } \\
\text { maintenance of complex data } \\
\text { processing infrastructures, clients' and } \\
\text { network applications; } \\
\text { - } \\
\text { the users can get a completely } \\
\text { ready for work virtualized workplace }\end{array}$ & \\
\hline
\end{tabular}

Any information product can be referred to the cloud technologies if it has a number of general characteristics, namely: self-service on demand (the user has the possibility to obtain computing resources independently and manage them without the help of system administrators); network availability (the service must be accessible from an arbitrary device, in a random place and at spontaneous time); measurable services (the user pays only for the used by him computing resources); flexibility (the possibility of an urgent change of the amount and time of usage of computing resources given for the user); independence from hardware (the provision of services should not depend on the working capacity of a particular hardware node) [6, p. 43].

In the analytical note of National Institute of Strategic Studies (2013) it is stated that the cloud solutions are considerably laconic, more productive and cheaper than the "hardware-wired" network. This is connected to the fact that the clouds allow to reduce significantly the capital expenses for construction of the data processing centers, the purchase of server and network equipment, hardware and software solutions, etc., and the cost for maintenance of the IT staff. The cloud technologies provide the possibility to change the configuration of the corporate IT infrastructure quickly, depending on current needs, consuming as much resources as necessary at the moment. The resources of clouds are usually enough for ordering of a virtual "supercomputer" or infrastructure for the enterprise, and to avoid the problems of software updating, the compatibility of different operating systems etc. In case of a mobile terminal device availability and access to the Internet, a user, regardless of his location, always has access to his own virtual computer, corporate networks, databases, etc. [15].

The mentioned characteristics are considered as the significant advantages of the cloud services, which determine their dissemination in all spheres of the human activity. The cloud services given by different providers (Amazon, Google, Microsoft, etc.) are now widely used at educational institutions. In particular, the web application packages for the educational institutions Google Apps Education Edition and Microsoft Office 365 for Education extend the possibilities of teamwork of pupils and teachers, students and tutors in the learning process. 
The number of benefits of usage of the Google Apps Education Edition package in education from the user's point of view are pointed out by the authors of the work [17], namely: the minimum hardware requirements; no expense of purchasing of special software; the possibility of usage in all operating systems; the possibility of work with documents with the usage of mobile devices that support work in the Internet; free applications [17, p. 108].

The cloud services are the base for the creation of a cloud-oriented environment at higher educational institutions, which is by itself "an educational and scientific environment in which for the realization of computer-procedural functions (content-technological and informationcommunicational) virtualized computer-technological (corporate or hybrid) infrastructure is purposefully built" [2, p. 59-60].

Under the cloud-oriented learning environment, the authors of the research [13] understand "an artificially constructed system that with the help of a cloud services provides learning mobility, group teamwork of teachers and students for effective and safe achievement of the didactic goals." [13, p. 12]. They also figure out the main characteristics of the COLE, namely: flexibility (the pupil can interact with the teacher individually, study in a convenient place at his own pace, give each topic as much time as is necessary for its mastering); structuring (the systematization of educational materials in accordance to curricula and programs); interactivity (the usage of communication, cooperation, cooperation for the exchange and the processing of various data); personalization (the orientation of the training to the development of the individual needs of the student); motivation (the student must be motivated, hard-working, needs to have the skill and desire to work independently); new role of the teacher (the teacher is the coordinator of student's development and continuous personal development); innovative activity of the student (the active, dynamic, mental and emotional activity of the student with the usage of cloud technologies during training and preparing of homework) [13, p. 14-16].

In the work [28] also the concept of cloud-oriented learning support system is introduced, which presents by itself such a system "in which the implementation of didactic goals implies the usage of cloud services and technologies, which provides the group teamwork of teachers and students, the development, the management, and also the spreading of educational materials with provision of the common access for subjects of educational process with the cloud technologies means." [28, p. 65].

The models of implementation of the cloud approach, which can be used in the process of creation of a cloud-oriented learning environment in the higher educational institutions, are provided by Bykov V. Yu [2, p. 89]:

- the creation and maintenance of own corporate cloud, which allows the construction, maintenance of functioning and ensuring of development of the own data processing center, as well as the arranging of a powerful ICT subdivision in the structure of higher education;

- the targeting at the public cloud, which implies the usage of tools and services of the external distributed network of data processing center on the conditions of full outsourcing, as well as the availability of its own ICT-subunit, the number of personnel and requirements to qualification which are less than in the case of usage of the corporate cloud;

- the orientation to the hybrid (composite) model of the implementation of ICT services (simultaneous usage of corporate and public clouds).

So, at the higher educational institutions the cloud technologies are now used for the organization of access to software, necessary due to the support of collective work, the realization of scientific research and training activity, conducting of the research and design developments, project implementation, etc. [2, p. 58]. The main benefits which a higher educational institution receives with the usage of the cloud technologies are: cost saving for software purchases; performance of various types of educational work, monitoring and evaluation of knowledge online; 
saving of computer memory; reduction of the need for specially equipped premises; openness of the learning environment for teachers and students [26, p. 18].

The marked advantages allow scientists to identify the main tendencies in the development of the cloud-oriented educational and research environment of higher educational institution, namely: the development of personalized learning environments; mitigating or removing access restrictions from any device, anywhere and at any time; improvement of teamwork services; development of service-oriented approach; creation of an unified ICT infrastructure of an educational institution; usage of both corporate and public resources; development of hybrid service models; extension of the "large data" approach during the design of pedagogical ICT systems; increase of requirements for compatibility, reliability, security, and others; reduction of the licensing and maintenance expenses [20, p. 65-66].

However, in the process of creation of COLE and the implementation of the cloud technologies in the learning process such factors should be taken into account which can hinder their effective usage, namely: the necessity of a permanent fast connection to the Internet; lower speed of programs performance than on local computers; lack of the cloud versions of the software or their limited functionality; a potential threat to the security and integrity of data [13, p. 24].

\subsection{The application of cloud technologies in the process of professional training of programmers}

The formation of competencies in the cloud computing is an important element in the professional training of future programmers in higher educational institutions. This competence implies the skill of usage of the cloud services in the professional activity for settling of the set tasks, as well as to adjust the cloud infrastructure, to develop the cloud software, and so on. In this regard, as is rightly noted by Seidametova Z. S. and Seidametov G. S., two directions of the study of the cloud technologies can be distinguished, namely: 1) the usage of the cloud services; 2) the development of cloud applications, the deployment of cloud infrastructure, the cloud applications security and data depository security support [19, p. 75].

The first direction is realized in the process of studying of the professionally-oriented disciplines, such as: "Programming", "Information Networks", "Parallel and Distributed Computing", "Introduction to Specialty", "Bases of Logical and Functional Programming", "Web Applications Programming and Support", "Computer Design" and others. The peculiarity of studying of these and other disciplines is the usage of various development environments, DBMS and many other programs. Nowadays there are cloud services that allow to learn programming languages, develop programs, create prototypes of interfaces, and so on. The usage of such services eliminates the necessity to install on your computers all the software you need for studies. Besides, some of these services provide the opportunity of organization of teamwork on projects.

For the programming in the cloud, web-oriented IDEs are assigned: Ideone, Codenvy, Cloud9, Koding, etc. They allow to use different programming languages in one environment, to run programs for accomplishment, to make search of errors, to organize teamwork, etc.

For example, the online IDE Ideone (Fig. 1) (https://ideone.com/) allows to write programs in more than 60 languages (C \#, C ++, Java, JavaScript, Objective-C, Perl, PHP, Prolog, Python and others.). In the text of the program syntax highlighting is used. For registered users, the possibility of discussion of the programs is accessible (with the usage of one of the social networks), as well as the exchange of links for familiarization with the results of work. The Ideone environment has certain limitations, in particular: the possibility to work with files is unavailable; the program execution time cannot exceed 15 seconds; available amount of RAM - no more than $256 \mathrm{MB}$. In this regard, this service can be used for the purposes of programming training, but not for the development of sufficiently large projects [16, p. 113-114]. 


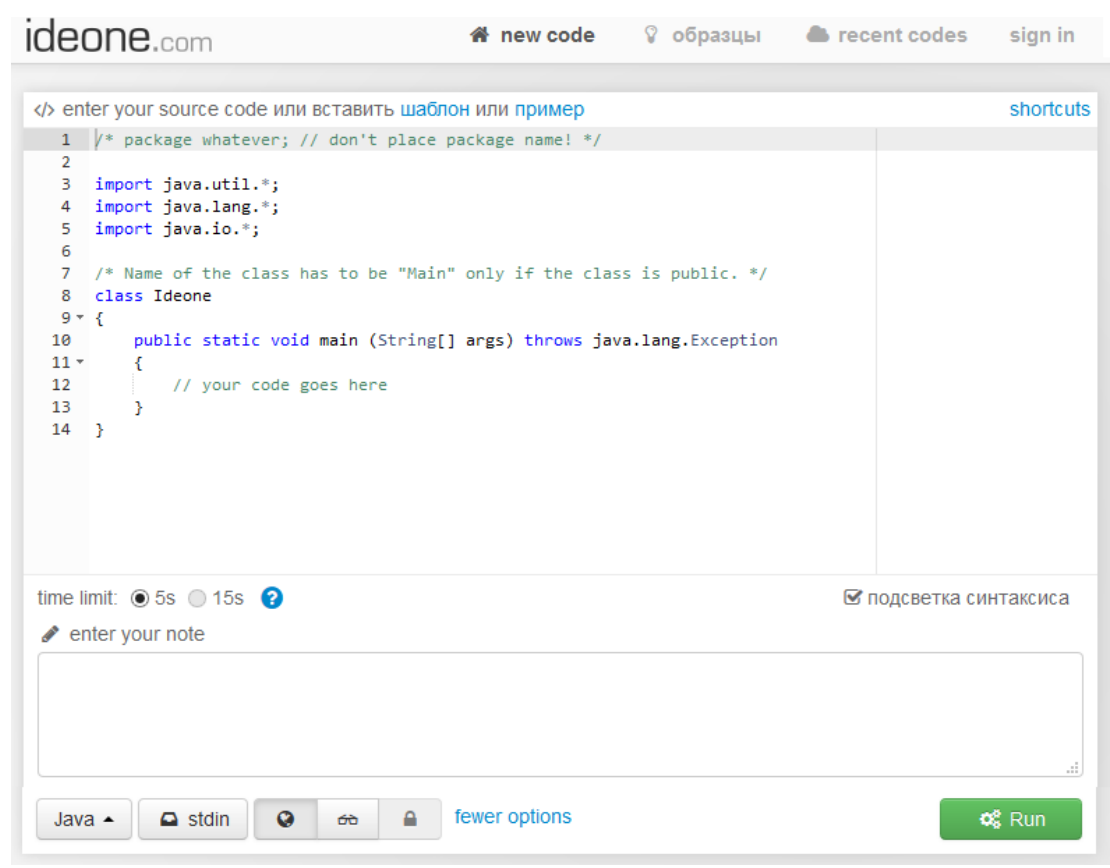

Fig. 1. Online-IDE Ideone

In the work [23] the results of the online IDE analysis are presented that can be used in the process of programming training (Ideone and Codepad), according to design (reliability, accessibility, free) and functional (the possibility of introduction of data-in by user, usability, multilingual) criteria. The research showed that the Ideone environment provides more qualitative software tool for students and teachers of higher educational institutions [23, p. 279-280]. We also point out that taking into account the above-mentioned features, as well as the availability of tools for debugging of programs and support of interpreted programming languages, the Ideone service is offered in the quality of the component of the cloud-oriented learning environment for the training of bachelors of informatics in higher educational institutions [27, p. 57].

So, with the help of IDE Ideone, it is possible to settle several tasks that occur in the process of programming training in higher educational institutions, namely: 1) to eliminate the necessity to install several IDE for studying of different programming languages; 2) to focus on mastering the skills of algorithmization and programming, as well as the syntax of programming languages instead of the time expense for learning the means of different environments development; 3) to organize the discussion of programs created by students; 4) to ensure the students with the opportunity of access to the learning environment and developed programs from any workplace where an Internet connection is available. At the same time, the lack of the possibility to develop applications with graphical interface and full teamwork on the program project, limits the sphere of usage of IDE Ideone in the process of the professional training programmers and allows to offer it in the quality of an environment for studying introductory programming courses at the basic (initial) level, as well as a compiler for testing the work capacity of written programs.

More powerful possibilities for the software projects development provides Codenvy's online IDE (Fig. 2) (https://codenvy.com/). The environment supports programming languages - Java, C ++ , JavaScript, PHP, Python, but the biggest attention is paid to the Java language. The IDE has a classic interface with a multifeatured main menu, windows and tabs for review of the tree of project files, code, results of accomplishment, etc. The developers are provided with such opportunities as: the creation and import of software projects, storing a project in the cloud, the creation of workspace, team development (the project owner creates a team, invites the participants to it and gives them access to the working space of the project), support of the Git version control system and the GitHub repository, syntax highlighting, the programs start for accomplishment, the search of mistakes and debugging of programs, and others. IDE Codenvy has a free tariff plan according to 
which the user is given 3GB of RAM for the starting of projects, as well as a possibility of team development for three people.

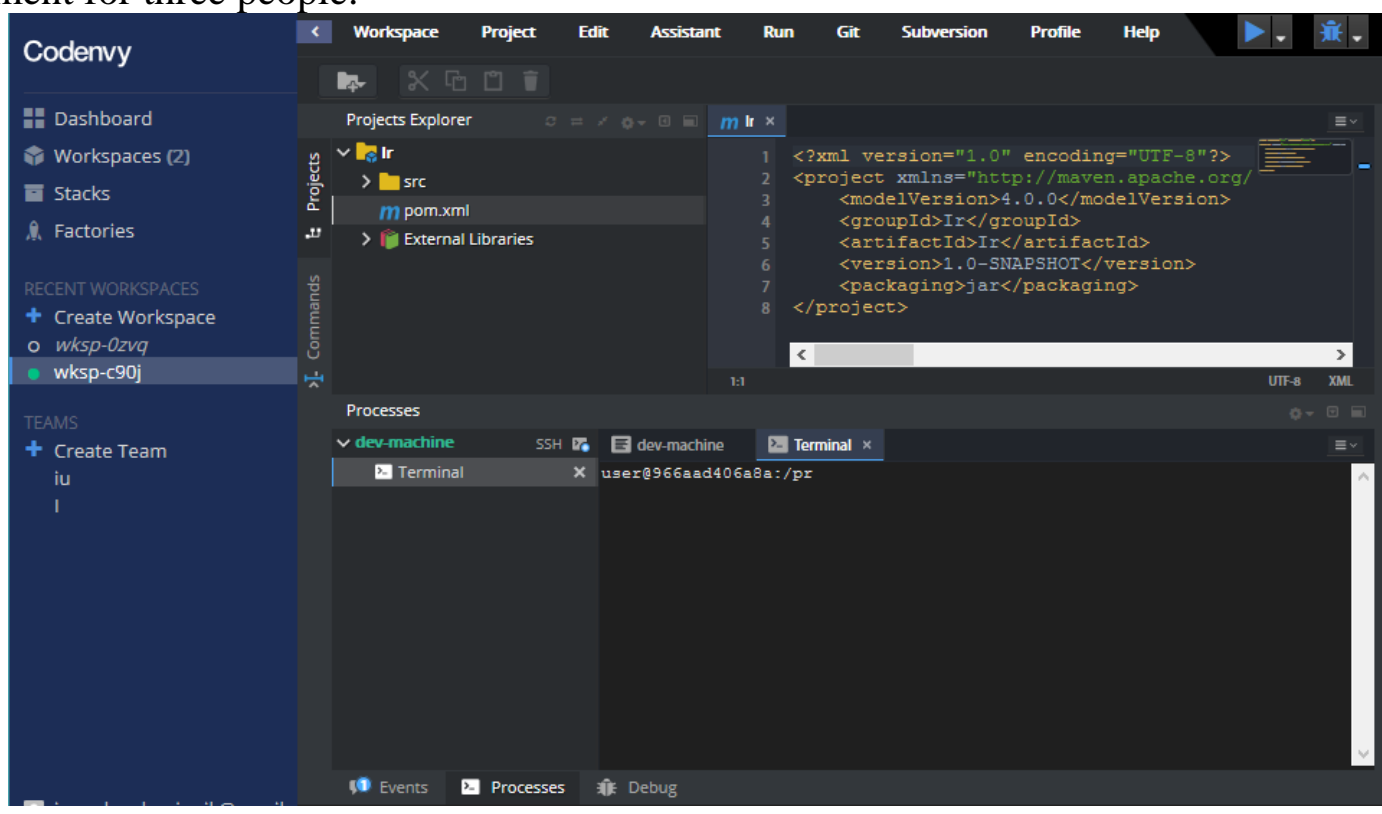

Fig. 2. Online-IDE Codenvy

In this way, the Codenvy environment can be offered for the usage in the process of professional training of programmers in higher educational institutions. Unlike the IDE Ideone, it is reasonable to use it for studying of the extended specialized programming courses (cross-platform programming, development of mobile and web-oriented applications, etc.). Very important in the view of the necessity of formation of teamwork skills is the possibility of collective development: in a free tariff, it is possible to organize the implementation of educational projects in microgroups by students.

In the quality of an alternatives to the considered environments other cloud IDEs can be offered, for example Codeanywhere (https://codeanywhere.com/) (Fig. 3) or Cloud9 (https://c9.io/), which are also assigned for online software projects development with the usage of different programming languages, debugging and executing of programs, storing of created programs in the cloud and access to them from any workplace. The possibilities of these services in free tariffs are limited, for example, the collective development means are not available or limited size of RAM is given, but this for the most part is enough for the accomplishment of educational tasks.

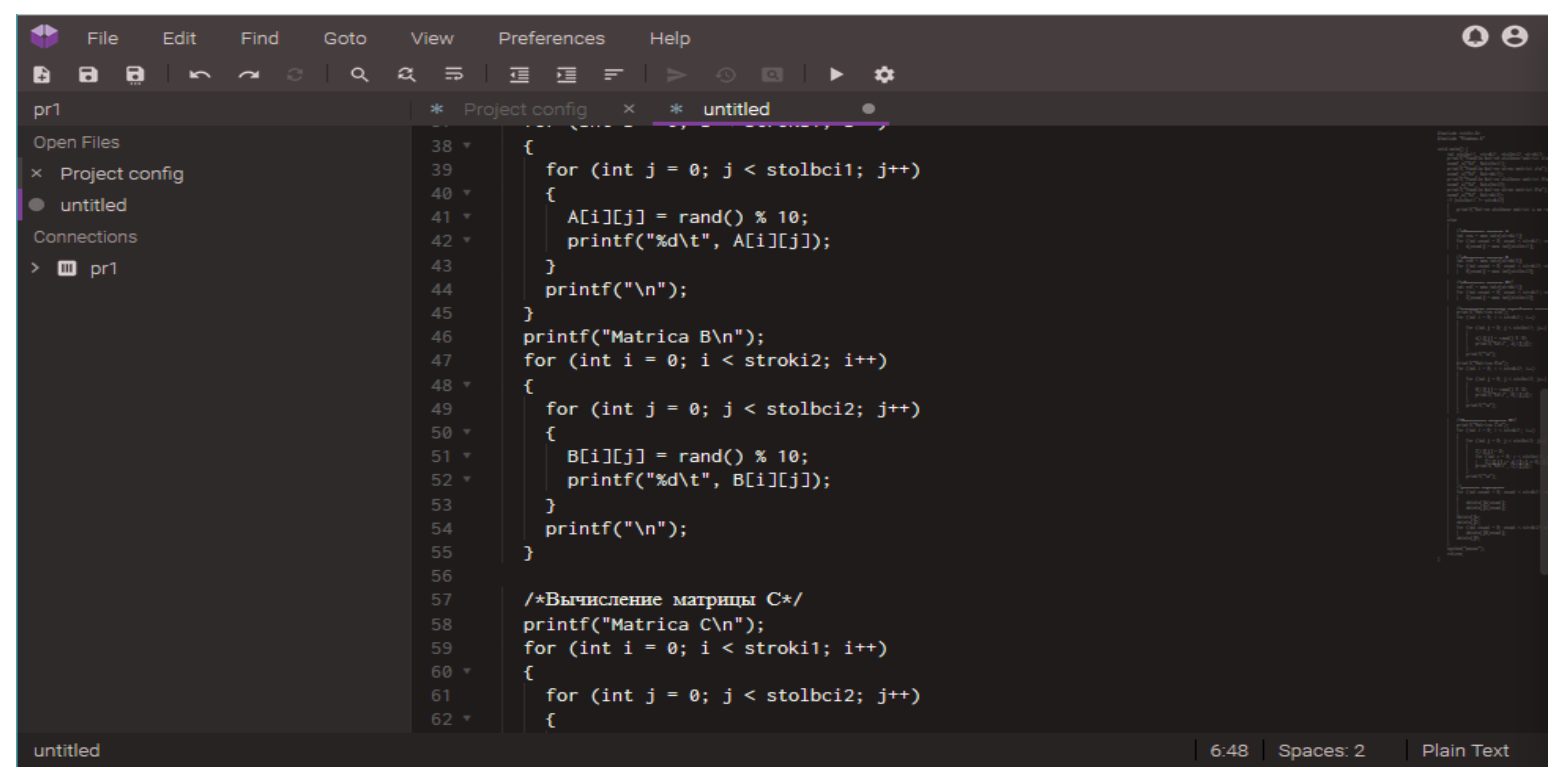

Fig. 3. Olnine-IDE Codeanywhere 
In the process of learning of the basics of web development (HTML, CSS, JavaScript), the cloud environments can also be used, for example online editors of the code CodePen (https://codepen.io/) (Fig. 4) or Cssdesk (http://www.cssdesk.com/). For example, in the CodePen editor, the possibility is given to see the result of executing of the code directly in the process of its writing, save your project in a cloud repository, and also to share it with other users. Among the professional tools, syntax highlighting and the usage of preprocessors should be pointed out. Besides, in the paid tariffs the possibilities are given for teamwork on the project (Collab Mode), the demonstration of work on the project in real-time in the virtual classroom (Professor Mode), and others. So, this editor is a good alternative for desktop web-editors.

For modeling of the databases in the course of studying the discipline "Databases and Information Technologies" (or other related courses), the service DbDesigner.net (Fig. 5) can be used, which allows to design the structure of the relation of database and then on the basis of this structure to generate SQL-Code for one of the databases automatically (PostgreSQL, SQLite, MySQL, MSSql, Oracle). The menu for this web application contains the commands for creation of a new outline, storing it in the cloud and downloading from there, giving shared access, creation of tables, etc. The created outline can be exported to a SQL script or graphic file [7]. It should be marketed that the service has a free tariff plan, under the conditions of which two models of the database can be created, each of which contains no more than 30 tables. This is enough for the implementation of an educational project, thus the service is appropriate to use in the process of training of programmers.

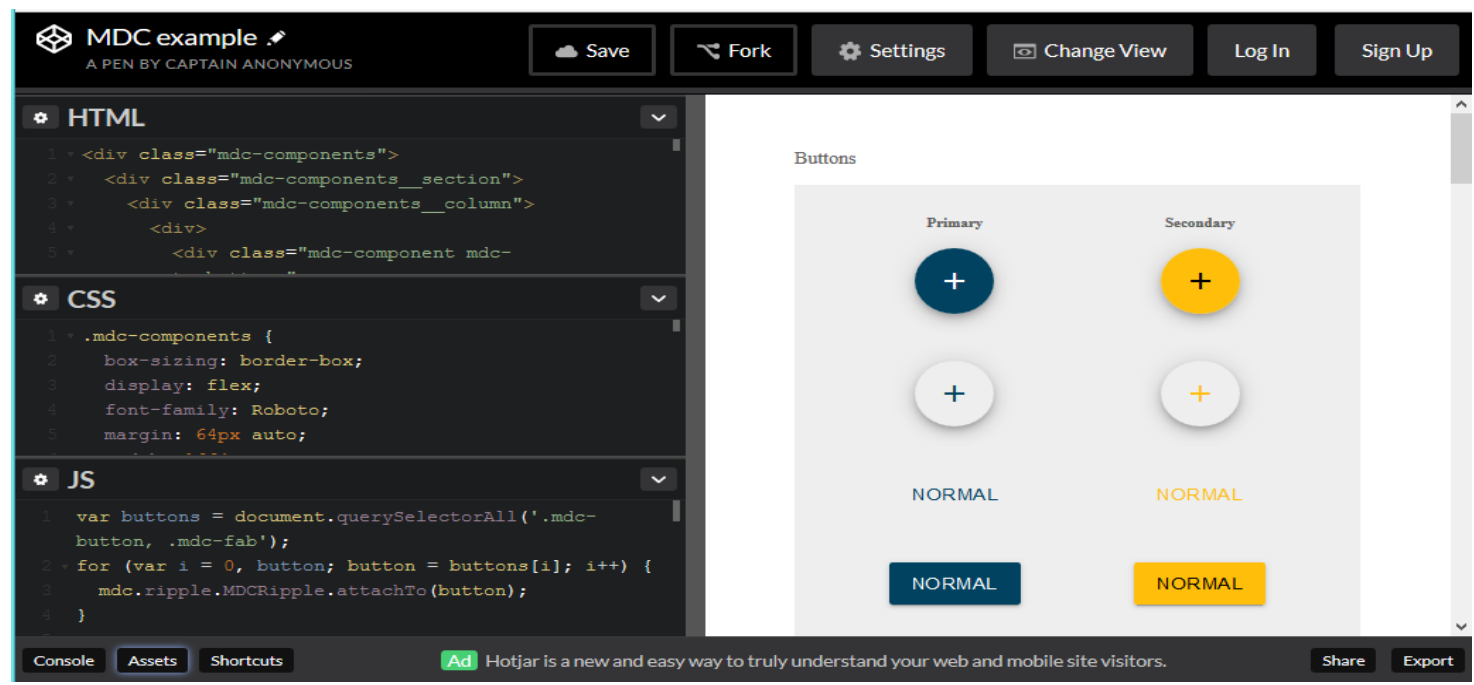

Fig. 4. Online editors of the code CodePen

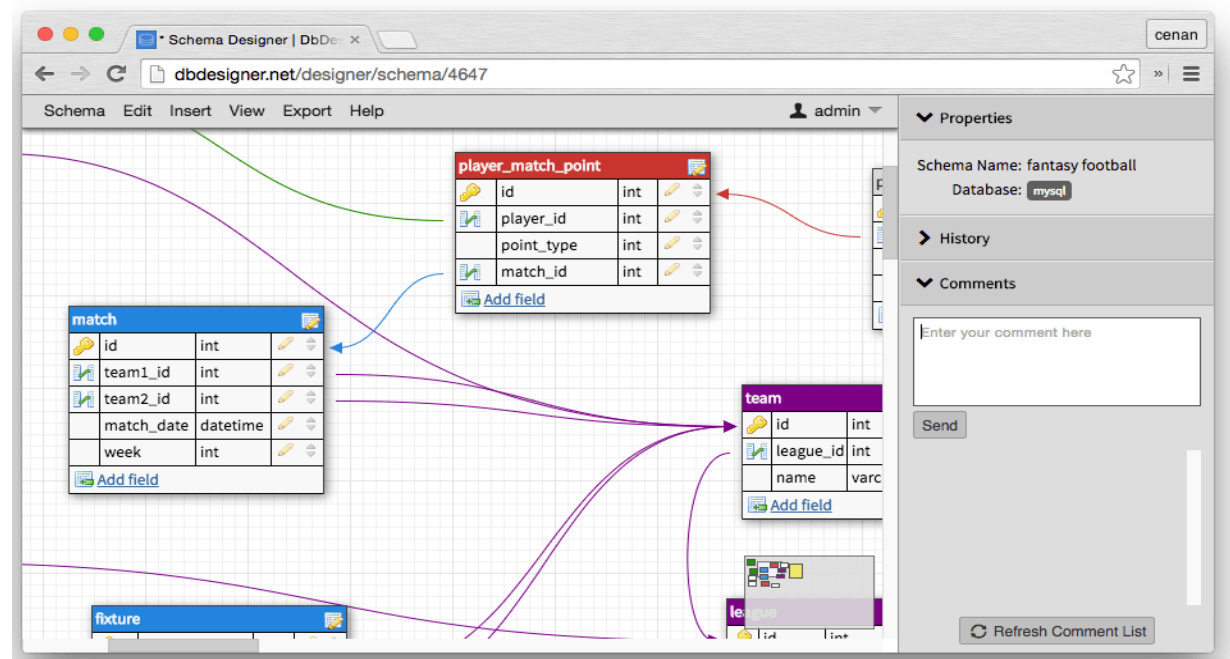

Fig. 5. Web-application DbDesigner.net [6] 
If the university has an appropriate computational infrastructure, teachers get an opportunity to design cloud resources. Such experience is described in the study of Smith A., Bhogal J., and Sharma M. [22]. They offer the prototype of innovative SaaS subject-based platform for e-learning CloudElearner, targeted at the learning of SQL. Developers distinguish three main elements in the CloudElearner structure: the 'DB Content Repository' (an area for storing learning materials), the 'SQL Practice Zone' (an area for practice with SQL), and 'Tests Zone' (an area for checking and assessment of knowledge). Thus the system allows students to acquire, apply, and check knowledge. Researchers notice "Combine this with the cloud benefits, we have a subject focused elearning system that is able to satisfy student learning requirements as well as overcome the common problems faced with e-learning via a traditional IT infrastructure." [22, p. 306].

The second direction of studying of the cloud technologies is realized by the way of introduction of specialized disciplines into the educational process, for example, "Cloud computing," as well as the special courses for studying of the architecture of cloud services from different providers (Amazon, Google, Microsoft, etc.). The study of these disciplines should be aimed at mastering the fundamental bases of the cloud technologies by students, mastering of the IT infrastructure planning methods of the enterprise in the conditions of implementation of the cloud solutions, formation of skills of usage of the cloud services and technologies of virtualization, and also usage and design of solutions according to the models IaaS, PaaS, SaaS [19, p. 76].

For the formation of enumerated skills, it is reasonable to use the Amazon cloud services that are provided within the program Amazon AWS Educate. This program is intended for the training of professionals in the field of the cloud computing in higher educational institutions. Educators, academic researchers, and students can apply to obtain free usage credits and can utilize on-demand infrastructure. The users of AWS Educate receive the access to cloud resources of the company for the accomplishment of computing and storing of information. Thanks to these virtual laboratories can be created in the clouds, the online courses can be conducted, and the research projects can be carried out $[10$, p. $131 ; 11]$.

\section{The conclusions from the conducted research}

The development of cloud computing is one of the prominent tendencies of the IT industry: the technology is being improved; the list of technologies and services that are offered to users is expanding. The enterprises, taking into account the possibilities of usage of modern IT infrastructure, software, reliable data bases under the conditions of outsourcing, are addressing increasingly to the service of cloud providers. In this regard, the introduction of cloud technologies and the creation of a cloud-oriented educational environment in educational institutions is an actual direction of informatization of the educational system. In particular, the usage of possibilities of cloud technologies allows to reduce the expenses for development of the IT infrastructure of higher educational institutions, to ensure the construction of an open educational environment, as well as to provide access to the computing power required for conducting of the research.

Another result of the development of cloud computing is the growing need for professionals in this field who possess the competence in the development and deployment of cloud software. In this regard, before higher educational institutions the task for the forming in future programmers' understanding of the fundamental bases of cloud computing arises, as well as the skills necessary for creation of the cloud services. The learning process should ensure the formation of skills of the usage of cloud services for settling of professional tasks, as well as skills in the developing of cloud applications, the deployment of cloud infrastructure, cloud applications security support and data bases. With this aim, it is reasonable to use the services for programming in "cloud", the organization of teamwork on projects, the program repositories and data, as well as the training opportunities given by the cloud providers. 


\section{REFERENCES}

1. Alkhansa, A., Shakeabubakor, A., Sundararajan, E. \& Hamdan, A.R. (2015) Cloud Computing Services and Applications to Improve Productivity of University Researchers. Inter-national Journal of Information and Electronics Engineering, 5(2), 153-157.

2. Bykov, V. Yu. (2013) Cloud computer-technological platform of open education and corresponding development of organizational-technological structure of IT units of educational institutions. The theory and practice of social systems management. NTU "KhPI".1, 81-98.

3. Bykov, V. Yu. \& Shishkina, M. P. (2016) Cloud technologies as an imperative for the modernization of the educational and scientific environment of a higher educational institution. The theory and practice of social systems management. NTU "KhPI", 4, 55-70.

4. Bykov, V. Yu., Spirin, O.M.\& Shishkina, M. P. (2015) Corporate Information Systems of the Scientific and Educational Activity Support on the Base of Cloud-Oriented Services. Problems and Prospects of the Formation of the National Humanitarian and Technical Elite: col. of scientif. works. NTU "KhPI", 43 (47), 93-121.

5. Cloud computing (world market) (2014) Retrieved from http://www.tadviser.ru/index.php/Article: Cloud_computing_(world_market).

6. Seidametova, Z. S., Ablyalimova, E. I., Medjitova, L. M., Seitvelieva, S. N.\& Temnenko, V. A. (2012) Cloud technologies and education. Simferopol: DIAIPI. 204.

7. Dbdesigner.net Retrieved from http://dbdesigner.net/.

8. Gorbatyuk, R. \& Potapchuk, O. (2016) Organization of remote education of future teachers of elementary education based on cloud technologies. Bulletin of the National Academy of the State Border Guard Service of Ukraine. Series: Pedagogy, 6. Retrieved from http://www.irbisnbuv.gov.ua/ cgi-bin/ irbis nbuv/ cgiirbis 64.exe? C21COM=2\&I21DBN=UJRN\&P21DBN= UJRN\&IMAGE_FILE_DOWNLOAD=1\&Image_file_name=PDF/Vnadped_2016_6_5.pdf .

9. Kirillov, I. (2017) Ukrainian market of cloud services-2016: foreigners tread? Networks and business, 3 (94), 24-32. Retrieved from http://sib.com.ua/sib-3-94-2017/04-ukrainskij-rynok-oblachnyhservisov-2016.html.

10. Khmil, N. A. (2015) Foreign and domestic experience of integration of cloud technologies in the pedagogical process of the higher educational institution. Information technologies and means of teaching, 50(6), 128-138. Retrieved from https://journal.iitta.gov.ua/index.php/itlt/article/view/1279.

11. Lakshminarayanan, R., Kumar, B. \& Raju, M. (2013) Cloud Computing Benefits for Educational Institutions. Second International Conference of the Omani Society for Educational Technology, Muscat, Oman. Retrieved from http://arxiv.org/ftp/arxiv/papers/1305/1305.2616.pdf.

12. Mell, P. \& Grance, T. (2011, September). The NIST Definition of Cloud Computing. Recommendations of the National Institute of Standards and Technology. NIST Special Publication 800-145. NIST, Gaithersburg, MD 20899-8930. Retrieved from http://nvlpubs.nist.gov/nistpubs/Legacy/SP/nistspecialpublication800-145.pdf.

13. Kopnyak, N., Korytska, G., Litvinova, S., Nosenko, Yu., Pojda, S., Sedoj, V., ... Shishkina, M. (2015) Modeling and integration of cloud-oriented educational environment services: monograph. Kiev, PC "Komprint".

14. Kremen, V.G. (2016) National report about the state and prospects of development of education in Ukraine. Kiev, Pedagogical thought.

15. National Institute of Strategic Studies (2013) Prospects of the cloud computing market development in Ukraine: benefits and risks. Analytical note. Retrieved from http://www.niss.gov.ua/articles/1191/\#_ftn2.

16. Rybakova,L.V. (2014) Cloud computing and ways of their usage in the educational process of modern higher educational institution. Kirovograd: KNTU. 15, 109-116.

17. Seidametova, Z. S. \& Seitvelieva S. N. (2011) Cloud services in education. Information technologies in education, 9,105-111. 
18. Sergienko, V. P. \& Vojtovych, I. S. Prospects of the usage of "cloud computing" in the educational activity of pedagogical universities. Scientific journal of NPU named after M. P. Drahomanov. 10, 58-63. Retrieved from http://nbuv.gov.ua/UJRN/Nchnpu $22011 \quad 107$.

19. Seydametova, Z. S. \& Seydametov, G.S. (2013) Teaching of cloud technologies of program engineers. Information technologies in education, 15,74-82.

20. Shishkina, M. P. (2015) Formation and development of the cloud-oriented educational and scientific environment of a higher educational institution. Kyiv: UkrISTEI.

21. Shyshkina, M. (2015) The Hybrid Service Model of Electronic Resources Access in the Cloud-Based Learning Environment. CEUR Workshop Proceedings, 1356, 295-310.

22. Smith, A., Bhogal, J. \& Sharma M.(2014) Cloud computing: adoption considerations for business and education. 2014 International Conference on Future Internet of Things and Cloud (FiCloud). 302307.

23. Spirin, O. M \& Vakalyuk, T.A. (2017) Criteria for the choice of open web-oriented technologies of the education of the programming bases of future teachers of informatics. Information technologies and means of teaching, 60(4), 275-287. Retrieved from https://journal.iitta.gov.ua/index.php/itlt/article/view/1815.

24. Spirin, O. M \& Vakalyuk, T.A. (2017) Web-oriented technologies of teaching of the programming bases of future teachers of informatics. Mathematics and Informatics in Higher School: Challenges of Modernity: col. of scientif. works on materials of Allukr. scientif-pract. conf., 18-19 $9^{\text {th }}$ of May 2017. 61-65.

25. Vakalyuk, T. A. (2015) Advantages of usage of cloud LMS NEO in comparison with other analogues in the design of a cloud-oriented educational environment for the training of bachelors of informatics. Collection of materials of the XII International Conference "Quality Strategy in Industry and Education" (30 ${ }^{\text {th }}$ of May $-2^{\text {nd }}$ of June, 2016, Varna, Bulgaria). International scientific journal Acta Universitatis Pontica Euxinus. Special edition. 505-510.

26. Vakalyuk, T. A. (2017) Model representation of cloud architecture for universities: the view of foreign scientists. Scientific Announcer of Melitopol State Pedagogical University. Series: Pedagogy, 18(1), 18-25.

27. Vakalyuk, T. A. (2017) Structural-functional model of the cloud-oriented educational environment for the training of bachelors of informatics. Information technologies and means of teaching, 59(3), 51-61. Retrieved from https://journal.iitta.gov.ua/index.php/itlt/article/view/1674/1190.

28. Vakalyuk, T. A. (2016) The model of the cloud-oriented system of support of the education of bachelors of informatics. Information technologies and means of teaching, 56(6), 64-76. Retrieved from https://journal.iitta.gov.ua/index.php/itlt/article/view/1415.

Стаття надійшла до редакції 17.08.2017

Спірін O.M. ${ }^{1}$, Сремєєв B.C. $^{2}$ Україна

${ }^{1}$ Інститут інформаційних технологій і засобів навчання НАПН України, Київ,

${ }^{2}$ Мелітопольський державний педагогічний університет імені Богдана Хмельницького, Мелітополь, Україна

ВИКОРИСТАННЯ ХМАРНИХ СЕРВІСІВ У ПРОЦЕСІ ПРОФЕСІЙНОӤ ПІДГОТОВКИ ПРОГРАМІСТІВ У ВНЗ

У статті проаналізований сучасний стан і наведені основні тенденції розвитку хмарних обчислень. Обгрунтована важливість упровадження хмарних технологій в освіті. Розглядаються напрями їх застосування у вищій освіті, зокрема створення у вищих навчальних закладах хмароорієнтованого освітньо-наукового середовища. Показані переваги переведення IT-інфраструктури ВНЗ до хмари (економія коштів на придбання програмного забезпечення й оновлення комп'ютерної бази; зменшення потреби у спеціально обладнаних 
приміщеннях; створення відкритого навчального середовища). Схарактеризовані основні напрями вивчення хмарних технологій у процесі професійної підготовки програмістів: 1) формування умінь використання хмарних сервісів для розв'язання фахових завдань; 2) формування умінь з розробки хмарних додатків, розгортання хмарної інфраструктури, підтримки безпеки хмарних додатків і сховищ даних. Надається опис хмарних сервісів, які можуть бути використані у процесі вивчення програмування і виконання навчальних проектів (Ideone, Codenvy, DbDesigner). Надається коротка характеристика можливостей використання платформи Amazon для формування умінь з розробки хмарного програмного забезпечення.

Ключові слова: хмарні обчислення, хмарні сервіси, хмароорієнтоване освітньонаукове середовище, професійна підготовка програмістів, програмування у «хмарі».

\section{Спирин О.М., Еремеев В.C.}

Институт информационных технологий и средств обучения НАПН Украины, Киев, Украина

Мелитопольский государственный педагогический университет имени Богдана Хмельницкого, Мелитополь, Украина

\section{ИСПОЛЬЗОВАНИЕ ОБЛАЧНЫХ СЕРВИСОВ В ПРОЦЕССЕ ПРОФЕССИОНАЛЬНОЙ ПОДГОТОВКИ ПРОГРАММИСТОВ В ВУЗАХ}

В статье проанализировано современное состояние и приведены основные тенденции развития облачных вычислений. Обоснована важность внедрения облачных технологий в образовании. Рассматриваются направления их применения в высшем образовании, в частности создание в высших учебных заведениях облачно-ориентированной образовательно-научной среды. Показаны преимущества перевода ИТ-инфраструктуры вуза в облако (экономия средств на приобретение программного обеспечения и обновление компьютерной базы, уменьшение потребности в специально оборудованных помещениях, создание открытой учебной среды). Охарактеризованы основные направления изучения облачных технологий в процессе профессиональной подготовки программистов: 1) формирование умений использования облачных сервисов для решения профессиональных задач; 2) формирование умений по разработке облачных приложений, развертыванию облачной инфраструктуры, поддержке безопасности облачных приложений и хранилищ данных. Дается описание облачных сервисов, которые могут быть использованы в процессе изучения программирования и выполнения учебных проектов (Ideone, Codenvy, DbDesigner). Приводится краткая характеристика возможностей использования платформы Amazon для формирования умений по разработке облачного программного обеспечения.

Ключевые слова: облачные вычисления, облачные сервисы, облачно-ориентированная образовательно-научная среда, профессиональная подготовка программистов, программирование в «облаке». 